\title{
Iryna Trunina
}

Kremenchuk Mykhailo Ostrogradskyi National University e-mail: truninairina0@gmail.com

ORCID: 0000-0002-7416-1830

\section{Kateryna Pryakhina}

Kremenchuk Mykhailo Ostrogradskyi National University e-mail:katerinapryakhina@gmail.com

ORCID: 0000-0002-5747-9492

\section{Kostyantyn Latyshev}

Kremenchuk Mykhailo Ostrogradskyi National University e-mail: latyschev.cost@yandex.ua

ORCID: 0000-0003-2645-1902

\section{Ksenia Skrebcova}

Kremenchuk Mykhailo Ostrogradskyi National University e-mail: kseniaskrebcova140996@gmail.com

ORCID: 0000-0002-9488-0082

\section{STRATEGIC DIRECTIONS OF THE SUSTAINABLE} DEVELOPMENT FOR THE CITY OF KREMENCHUK IN UKRAINE STRATEGICZNE KIERUNKI ZRÓWNOWAŻONEGO ROZWOJU MIASTA KRZEMIEŃCZUK NA UKRAINIE

DOI: $10.15611 / \mathrm{br} .2020 .1 .14$

JEL Classification: H75 O18, R50, Q01

(C) 2020 Iryna Trunina, Kateryna Pryakhina, Kostyantyn Latyshev, Ksenia Skrebcova This work is licensed under the Creative Commons Attribution-ShareAlike 4.0 International License. To view a copy of this license, visit http://creativecommons.org/licenses/by-sa/4.0/

Quote as: Trunina, I. Pryakhina, K., Latyshev, K., and Skrebcova, K. (2020). Strategic directions of the sustainable development for the city of Kremenchuk in Ukraine. Biblioteka Regionalisty. Regional Journal, (20). 


\begin{abstract}
The article addresses the theoretical aspects of sustainable development; the content of methodological approaches to the assessment of sustainable city development is determined, the system of evaluation of sustainable city development is characterized, the dynamics of economic, social and ecological development of Kremenchuk are analyzed and recommendations for improving the sustainable development of the city are developed. The purpose of the research was to develop measures to improve the economic, social, environmental components of sustainable development of the Ukrainian industrial city of Kremenchuk.
\end{abstract}

Keywords: local self-government, the sustainable urban development concept, components of the concept: economic, social and environmental.

Streszczenie: W artykule poruszono teoretyczne aspekty zrównoważonego rozwoju, a także metodologiczne podejścia do oceny zrównoważonego rozwoju miasta. Scharakteryzowano system oceny zrównoważonego rozwoju miasta, przeanalizowano dynamikę rozwoju gospodarczego, społecznego i ekologicznego miasta Krzemieńczuk, opracowano zalecenia dotyczące poprawy zrównoważonego rozwoju miasta. Celem badań było opracowanie działań na rzecz poprawy ekonomicznych, społecznych i środowiskowych komponentów zrównoważonego rozwoju ukraińskiego miasta przemysłowego - Krzemieńczuka.

Słowa kluczowe: samorząd, koncepcja zrównoważonego rozwoju miejskiego, elementy składowe pojęcia: ekonomiczne, społeczne i środowiskowe.

\title{
1. Introduction
}

The current problems of urban development cannot be solved solely by increasing public funding for modern institutions and organizational purposes. An important component of city development is a properly chosen strategy. It is necessary to develop such a strategy that will allow for achieving economic development and the simultaneous solution of environmental problems. This should be provided for the creation of new jobs, ensuring a healthy environment, reducing mortality and achieving a qualitatively new standard of living for residents. Sustainable development allows the city government to develop an integrated approach to environmental, economic and social challenges, and to work in partnership with urban communities.

The purpose of the research was to develop measures to improve the economic, social, environmental components of the sustainable development of the Ukrainian industrial city of Kremenchuk.

To achieve this goal, the following tasks were set and addressed:

- investigation of the theoretical aspects of the city sustainable development assessment system of the concept of sustainable development;

- analysis of the dynamics of the economic, social and environmental development of Kremenchuk;

- proposal for the directions and methods of updating the strategy of sustainable development of Kremenchuk through the implementation of programmes.

The rationale of the theoretical foundations of sustainable development of the regions is studied in its scientific and practical aspect, which is reflected in the works 
by T. Vlasova, L. Katan, A. Sport, L. Kvyatkovskaya, L. Marchuk, etc. in which the concept of sustainable development appeared by association. However, despite the diversity of theoretical and methodological research, the problem of ensuring sustainable development of the region and setting key priorities is worth it quite notable. The problem of the basics of sustainable development forecasting has been explored by many economists and scientists of other disciplines, but the following authors made a significant contribution to solving this problem: Gerasymchuk and Vakhovych characterize "sustainable development" as a process of socio-economic development, provided that the ecological balance of the socio-ecological-economic system of a certain social formation is ensured (Gerasymchuk and Vakhovich, 2002). According to Berdanova, Vakulenko, Tertichka, in the system of public administration, strategic planning is considered as a process and as a result, however the choice of goals and objectives is based on strategic planning, while determining the most effective way to achieve goals and objectives is the planning process itself (Berdanova, Vakulenko, and Tertichka, 2008). Yet at this time of economic crisis, this topic is becoming even more urgent and requires effective models of forecasting the development of regions, which will contribute to the development of the economy as a whole.

The scientific novelty of the results of scientific work is the solution of an important scientific and practical task - the formation of a system of indicators to assess and improve the work of local governments in developing the concept of sustainable development.

\section{Methods for assessing the potential for sustainable city development}

The main objective of the Sustainable Development Strategy is to create a modern European city attractive for living and working in, based on the efficient use of available resources, the existing competitive advantages of the city, environmental protection and human capital development, as well as the introduction of innovations and global best practice for sustainable development management. To assess the potential of sustainable development, three main components of the sustainable development system are identified: economic, social, environmental.

The economic assessment of the potential for sustainable development is the idea of economic impact assessment, i.e. the use of value, goes beyond the basics of a socially oriented economy. Human well-being depends on the quantity and quality of not only consumer goods, but also the flow of goods and services from ecosystems, such as health, outdoor recreation and others. Thus, the economic value of ecosystem change should be measured by reference to the impact on human well-being.

The social assessment of the potential for sustainable development is the impact on people and their interaction with the environment. The purpose of social impact assessment is to determine the future consequences of continuing 
or implementing proposed actions that are relevant to individuals, organizations and social macrosystems. According to this definition, social influence is derived from any human activity that changes the way people live, work, communicate, their health and needs. The basis for social impact analysis is the assessment of the consequences of the implementation of policies, programs, initiatives and actions on social, institutional and individual behavior.

The environmental assessment of sustainable development potential is the potential environmental impact. The main legislative acts in the field of ecological and economic assessment in Ukraine are the following laws: "On the environment" (1991) and "On ecological expertise" (1995).

When selecting indicators for assessing sustainable urban development, a number of requirements should be considered:

- the scores should cover all components of the regional system: economic, social and environmental;

- the number of indicators should be limited;

- the indicators should be comparable;

- the information base for the assessment should be accessible;

- the thresholds are required to interpret the integral estimate.

The figure below shows the components of the city's sustainable development assessment systems and selected indicators (Figure 1).

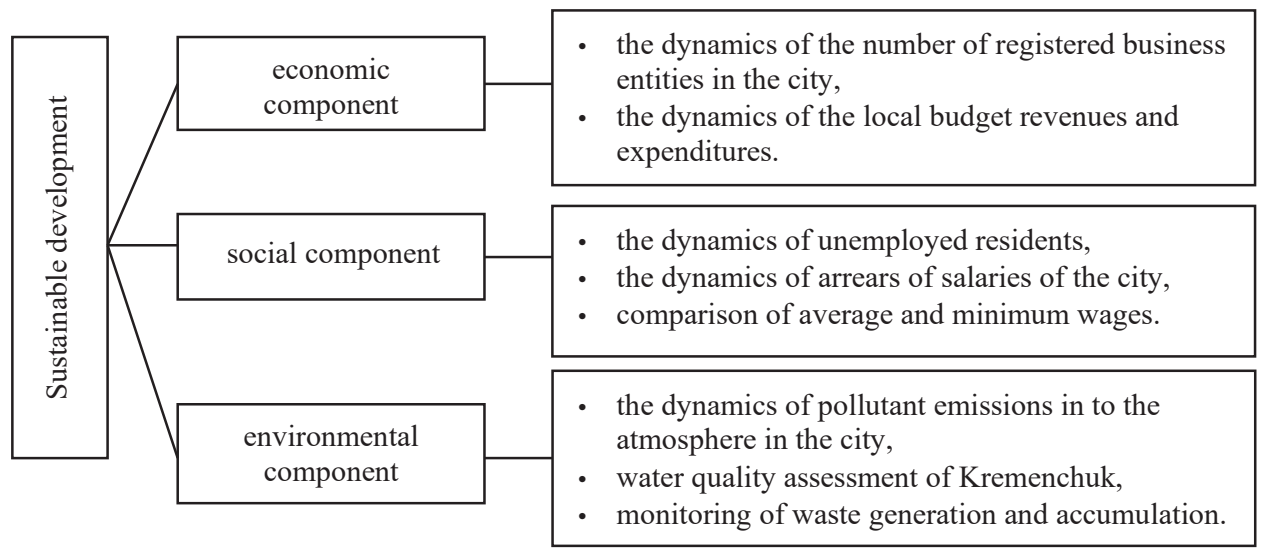

Fig. 1. Components of sustainable development systems

Source: author's elaboration.

During the research the operative-diagnostic method was used, and to a lesser extent the method of analytical dependencies. Thus, in order to determine the level of development of sustainable development of Kremenchuk, it was necessary to 
use the methodologies to carry out an analysis of the three main components of sustainable development allowing to determine the level of development of the city.

\section{Analysis of the components of sustainable development of Kremenchuk}

Kremenchuk is an industrial city, one of the largest in Ukraine, as it contains $60 \%$ of the industrial enterprises of the region. The city is among the contributors of the budget of Ukraine, its part is about 7\%. Figure 1, analyses the sustainable development of the city of Kremenchuk (Kremenchuk City Development Strategy).

\subsection{Evaluation of the economic component}

The stable operation of enterprises in Kremenchuk attracts investors. The amount of foreign capital invested in the city's economy is constantly growing and originates from 26 countries. Creating a favourable environment for the formation and functioning of business entities is considered by the city authorities as one of its priorities (Table 1).

Table 1. Dynamics of the number of registered business entities in the city of Kremenchuk

\begin{tabular}{|l|c|c|c|}
\hline \multicolumn{1}{|c|}{ Indicators } & \multicolumn{3}{c|}{ Period of study } \\
\cline { 2 - 4 } & 2016 & 2017 & 2018 \\
\hline $\begin{array}{l}\text { Number of small and medium-sized enterprises, } \\
\text { including units }\end{array}$ & 14986 & 14219 & 14270 \\
\hline $\begin{array}{l}\text { Number of employees of small and medium-sized } \\
\text { enterprises }\end{array}$ & 28074 & 27987 & 28681 \\
\hline $\begin{array}{l}\text { Proportion of revenue from small and medium-sized } \\
\text { enterprises to budgets of all levels, \% }\end{array}$ & 76.96 & 77.8 & 78.4 \\
\hline $\begin{array}{l}\text { Share of small and medium-sized enterprises in total } \\
\text { output of products (works, services), \% }\end{array}$ & 29.7 & 81.2 & 83.6 \\
\hline
\end{tabular}

Source: analysed by the author on the basis of (The Program of Economic and Social Development..., n.d.).

According to Table 1, the share of small and medium-sized enterprises in the total output of products (works, services) is currently 83.6\% (UAH 22177330 thousand), which is $1.5 \%$ more than in the corresponding period of 2017 . At the same time, in absolute terms, this indicator increased by UAH 9171951,8 thousand, which is related to the change of criteria for determining large taxpayers and their transfer to the category of medium-sized business entities.

The share of revenue from small and medium-sized enterprises to budgets of all levels for the reporting period increased by $19.30 \%$. The increase in the share of revenues was influenced by: 
- the increase of the subsistence minimum for able-bodied persons and the minimum wage since January 1, 2018;

- the increase of the taxable income of taxpayers in connection with the increase of prices for goods and services.

At the same time it should be noted that data on indicators of small and medium-sized enterprises were based solely on the available information of the Kremenchuk tax inspectorate. In 2018, according to the criteria set by the Tax Code of Ukraine, the following Kremenchuk enterprises were classified into the category of large taxpayers: PJSC "Ukrtatnafta”, PJSC "JTI International Ukraine”, PJSC "KVBZ", PJSC "Kremenchuk Steel Plant", PJSC "Kredmash" (Kratt, Pochtovyuk, Trunina, and Pryakhina, 2019).

To reduce the pressure on economic entities and to support small businesses, promote self-employment and create additional jobs for them, the Kremenchuk City Council for 2017 and 2018 approved a flat rate of 10\% for taxpayers in I and II groups. It was important for entrepreneurs to reduce the single tax rate by $50 \%$ for single taxpayers of Group II. At the same level, the rates of the single tax rate for the Kremenchuk City Council were approved for 2019. Property tax rates were not increased either.

This year the number of economic entities (legal entities and entrepreneurs) working under the simplified taxation system as of 01.10 .2018 is 8258 persons, which is 41 entities more than in the beginning of the current year (by 01.10.2017 8112 economic entities, on 01.01.2018 - 8217 economic entities).

The number of employees of small and medium-sized enterprises as of 01.10.2018 is 28681 persons, which is 694 units more than in the corresponding period of 2017 (27 987 persons).

Today, a significant share of the city budget is taxed on the income of small and medium-sized businesses, and accordingly the expenditures of the city budget depend on the number of business entities (Figure 2).

According to the figure the main sources of revenue that form the revenue part of the general fund of the city budget are four taxes, which make up about $96.1 \%$ of the revenue part of the general fund: tax and levy on personal income $-63.3 \%$, property tax on land tax $-16.0 \%$, excise tax $-8.4 \%$, single tax $-8.4 \%$. In terms of expenditure, half are social protection and social security, education $22 \%$, health care $13 \%$, housing and communal services $5 \%$, etc.

Analysing the economic component of the sustainable development strategy, one can conclude that small and medium-sized enterprises contribute to the city budget significantly, but one of the key functions that is extremely important is job creation. The number of employees of small and medium-sized enterprises in the city is 28681 persons.

Accordingly, it is necessary to develop measures contributing to the development, increase the number of business entities, namely measures aimed at: implementing 

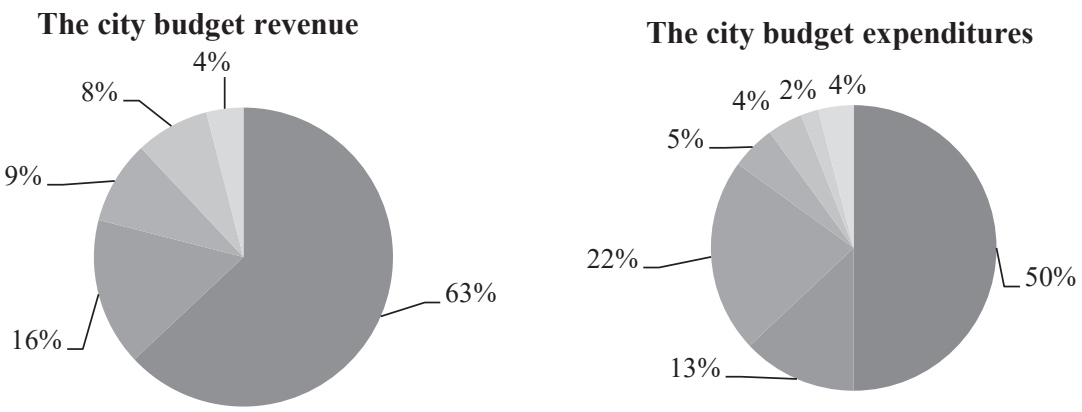

w small and medium business income tax

nocial protection and social security

health care

property tax in respect of land tax

- excise tax on sales of excisable goods by

education

utilities

retailers

single tax

governance

culture and art

others expenses

other expences

Fig. 2. City budget revenues and expenditures.

Source: analysed by the author on the basis of (The Program of Economic and Social Development..., n.d.).

a regulatory policy to simplify the procedures for starting a business; fostering an entrepreneurial environment and eliminating red tape; holding short-term training seminars for small and medium business development entrepreneurs (Sushchenko, Trunina and Khovrak, 2019).

\subsection{Evaluation of the social component}

There are 29 general education institutions in Kremenchuk, including 3 secondary schools ("liceum"), 2 high schools, 1 college, 2 specialized schools with advanced English language and advanced study of physical culture and health basics, specialized boarding school No. 21 with advanced subjects and one evening school. The training of specialists in Kremenchuk is carried out by 6 vocational schools, and 2 higher educational establishments where over 16 thousand pupils and students receive higher and vocational education, of which over 6.5 thousand acquire work professions. The health care of the city population is provided by 27 health care institutions (The Program of Economic and Social Development ..., n.d.).

One of the equally important indicators in the effective social activity of the city is providing the population with employment. Therefore, the work of local authorities in Kremenchug should be aimed at the implementation of specific measures aimed 
at ensuring productive employment of the population, facilitating the return of unemployed citizens to employment, and preventing large-scale unemployment (Table 2).

Table 2. Dynamics of unemployed residents of the city during 2016-2018

\begin{tabular}{|l|r|r|r|}
\hline \multirow{2}{*}{ Indicators } & \multicolumn{3}{c|}{ Period of study } \\
\cline { 2 - 4 } & 2016 & 2017 & \multicolumn{1}{c|}{2018} \\
\hline Number of unemployed residents & 2700 & 2754 & 2492 \\
\hline Total number of inhabitants & 222309 & 222325 & 220245 \\
\hline The share of unemployed in the total population, \% & 2.150 & 1.238 & 1.121 \\
\hline
\end{tabular}

Source: analysed by the author on the basis of (The Program of Economic and Social Development..., n.d.).

Analyzing the data shown in Table 2, one can conclude that in the period 2016-2018 the number of unemployed residents of the city increased, as the local industry is historically linked to the Russian market - traditionally about $70 \%$ of production went there. However, in this period the dynamics of the number of unemployed in the city is visible, therefore in 2018 their number was 2 492, which is 262 fewer than in the previous year.

Analysing the Table 3, there is a gradual decrease of arrears of payment of wages to employees during 2016-2018.

Table 3. Dynamics of wage arrears to employees of economically active enterprises of Kremenchuk

\begin{tabular}{|l|c|c|c|}
\hline \multirow{2}{*}{ Indicator } & \multicolumn{3}{|c|}{ Period of study } \\
\cline { 2 - 4 } & 2016 & 2017 & 2018 \\
\hline $\begin{array}{l}\text { The amount of arrears of wages to employees } \\
\text { economically active enterprises, thousand UAH }\end{array}$ & 961.7 & 753.1 & 668.4 \\
\hline
\end{tabular}

Source: analysed by the author on the basis of (The Program of Economic and Social Development..., n.d.

Table 4. Comparison of the average and minimum wages of Kremenchuk

\begin{tabular}{|c|c|c|}
\hline Years/ indicators & $\begin{array}{c}\text { The average monthly nominal wage } \\
\text { of one staff member, UAH }\end{array}$ & Minimum wage, UAH \\
\hline 2016 & 4678 & 1450 \\
\hline 2017 & 6914 & 3586 \\
\hline 2018 & 9231 & 5903 \\
\hline
\end{tabular}

Source: analysed by the author on the basis of (The Program of Economic and Social Development..., n.d.). 
According to the data in Table 4 for 2016, the average wage of one full-time employee of enterprises, institutions, organizations (with the number of employees of 10 and more persons) in January-September 2016 was 4678 UAH. In 2017, compared to 2016, wages increased to UAH 6914 and the minimum wage to UAH 3586. In 2018, the average salary is $9231 \mathrm{UAH}$ and the minimum was $5903 \mathrm{UAH}$. The criterion that influences the amount of wages is the length of working time.

Thus, during 2014-2016, the overall population decline slowed significantly due to a decrease in mortality. However, in the period 2016-2018 there was a decrease in the population of the city, due to the negative dynamics of migration (in 2016, 522 people left the city). The city has a significant number of internally displaced persons -3892 persons, representing $1.75 \%$ of the total population. The number of IDPs per 10 thousand population is 175 . The average monthly salary calculated per employee in 2017 was 6914 UAH. In 2018 the salary was $9231 \mathrm{UAH}$.

Thus, the city authorities should pay attention to: ensuring payment of wages at a level not lower than the minimum; prevention of violations of labour legislation in terms of remuneration and elimination of wage arrears; creating comfortable and safe living conditions for the population; modernization of primary and secondary care; ensuring the accessibility and quality of social services in the fields of social protection, culture, physical culture and sports.

\subsection{Evaluation of the ecological component}

The environmental situation in the city is characterized by its relative stability, but there are many problems that need to be addressed. Each year, from the stationary and mobile sources of pollution, from 170 to 180 thousand tons of pollutants are added to the atmosphere of the Poltava region, where $29.7 \%$ of all the pollutant emissions into the atmosphere are from the stationary sources in Kremenchuk.

Per person residing in Kremenchuk, the amount of emissions is $45.5 \mathrm{~kg}$. This figure is lower than the average in Ukraine by 2.1 times. Based on the square kilometer of the territory of the region, the emission density from stationary sources of pollution is 2,316 tons of harmful substances, less than the average in Ukraine by 3.1 times (Table 5).

Table 5. Emissions of pollutants into the air

\begin{tabular}{|c|c|c|}
\hline Year/Indicators & $\begin{array}{c}\text { Emissions of pollutants, } \\
\text { thousand tons }\end{array}$ & $\begin{array}{c}\text { Carbon dioxide emissions, } \\
\text { million tonnes }\end{array}$ \\
\hline 2015 & 141.0 & 4.7 \\
\hline 2016 & 56.2 & 3.4 \\
\hline 2017 & 55.9 & 3.6 \\
\hline 2018 & 52.2 & 3.3 \\
\hline
\end{tabular}

Source: analysed by the author on the basis of (The Program of Economic and Social Development..., n.d.). 
In Kremenchuk, there are many businesses located close to the residential quarters, and some houses are actually next to production sites. This fact leads to numerous complaints by residents about the poor living conditions associated with the work of businesses due to increased air pollution, noise and vibration. Kremenchuk has the highest density of harmful substances per capita in the region (206.1 tonnes). More than half of all atmospheric emissions are provided by mobile sources, of which the lion's share is in motor transport.

The only source of drinking water supply for the population of Kremenchuk is the local reservoir. In the summer, the state of water resources deteriorates and has marginal values. Seasonal deviations (oxygen level decreases, manganese content increases) are observed in the local water intake area in the summer months at high air temperatures and wind speeds up to $2 \mathrm{~m} / \mathrm{min}$. in deep water samples (the intake gauge is located at the bottom of the reservoir at a depth of almost $14 \mathrm{~m}$ ). The problems are the 'flowering' of water, and the development of bacteria.

An important issue is the number of poisonous substances and bacteria in the Dnieper river. As of June 2019, the index of lactose-positive bacteria was 700000 at the rate of 10000 . This resulted in a number of infectious diseases, increased mortality of river fish, and the deterioration of the river on the whole.

Compared to the previous years, by the main indicators of water quality, the water quality of the Dnieper Falls during June 2019 tended to deteriorate, as shown in Table 6.

Table 6. Water quality analysis of the Dnieper Falls

\begin{tabular}{|l|l|}
\hline \multicolumn{1}{|c|}{ Year } & \multicolumn{1}{c|}{ Conclusion } \\
\hline With appropriate periods 2001-2008 & improved condition \\
\hline With appropriate periods 2009-2014 & improved condition \\
\hline With appropriate periods 2015-2017 & improved condition \\
\hline With the corresponding month of June 2018 & of a similar condition \\
\hline From the previous month in May 2019 & $\begin{array}{l}\text { of a similar condition, with a tendency to } \\
\text { seasonal deterioration of water quality }\end{array}$ \\
\hline
\end{tabular}

Source: analysed by the author on the basis of (Characteristics of the Dnieper Basin during March 2019, n.d.).

The main reasons for the deterioration of the water quality in the rivers are the poor efficiency of the sewage treatment plants, and the deteriorating condition of the sewage networks, the pumping stations and the storm sewer facilities. Most sewer networks require major overhaul or replacement.

One of the major environmental problems of the city is the municipal solid waste landfill. The landfill has existed since 1965, and in 2017 the thicker layer of accumulated waste in the landfill was $40 \mathrm{~m}$, which is $80 \%$ of the load, generation and accumulation of waste as shown in Table 7. 
Table 7. Waste generation and accumulation, thousand tons

\begin{tabular}{|c|c|c|c|}
\hline Indicators & 2014 & 2015 & 2016 \\
\hline \multicolumn{4}{|c|}{ Waste generation } \\
\hline I-IV danger classes - total & 1114.3 & 232.8 & 119.3 \\
\hline including I-III classes of danger & 74.5 & 37.1 & 19.1 \\
\hline \multicolumn{4}{|c|}{ Availability of waste at the end of the year } \\
\hline I-IV danger classes - total & 20238.6 & 20397.8 & 20482.1 \\
\hline including I-III classes of danger & 16.8 & 12.1 & 13.4 \\
\hline
\end{tabular}

Source: analysed by the author on the basis of (Report on the Strategic Environmental Assessment..., n.d.).

According to Table 7, there is a significant decrease in the amount of accumulated waste in the period 2014-2016, but the problem remains unsolved because the existing landfill is almost full. There is no alternative for a new landfill in the city. Therefore, the priority environmental task for Kremenchuk is the construction of a modern waste disposal plant, which will contribute to the overall improvement of the recycling of household waste.

Thus, the analysis of the components of sustainable development of the city showed that in the economic component it is necessary to create a favourable environment for entrepreneurial activity, the social component of the city needs to improve the quality of life of the population, increase the level of education, environmental needs to address the issue of waste disposal, improvement of the atmospheric air, and the quality of water resources.

\section{Directions to improve sustainable development of Kremenchuk}

The analyzed indicators make it possible to identify the targets to be implemented by the Kremenchuk Sustainable Development Strategy and to structure them into components and areas of sustainable development. These data are detailed in the form of a goal tree, which is used as a basis for the preparation of the Kremenchuk Sustainable Development Strategy.

The proposed directions will significantly improve the sustainable development of the city, namely the economic situation of the city, the quality of life of the population will increase, and the quality of the environment will be at the proper level. Therefore, in order to apply the recommendations given to local self-government on sustainable development of the city, it is proposed to implement the following developed programmes, see Table 8 . 


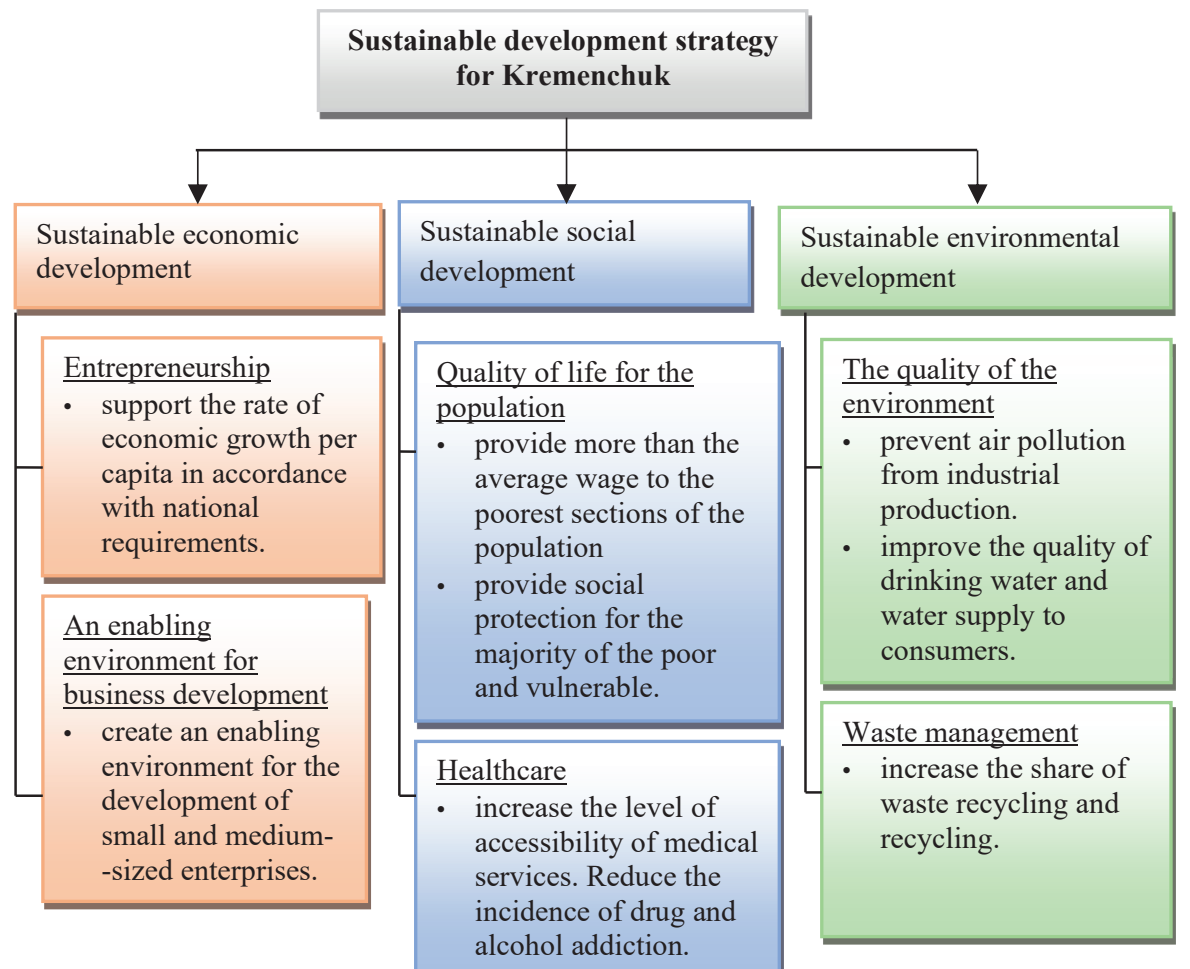

Fig. 3. Kremenchuk Sustainable Development Strategy Goal Tree

Source: authors' elaboration.

Table 8. Developed programmes

\begin{tabular}{|l|l|}
\hline \multicolumn{1}{|c|}{ Programme } & \multicolumn{1}{c|}{ Goal } \\
\hline \multicolumn{1}{|c|}{1} & \multicolumn{1}{c|}{2} \\
\hline $\begin{array}{l}\text { Targeted Small } \\
\text { and Medium Business } \\
\text { Support Programme }\end{array}$ & $\begin{array}{l}\text { The programme is aimed at creating favourable conditions for the } \\
\text { development of small and medium-sized businesses in Kremenchuk. }\end{array}$ \\
\hline Employment Programme & $\begin{array}{l}\text { The purpose of the programme is to involve the unemployed residents } \\
\text { of the city in community service. Accordingly, it is necessary to increase } \\
\text { the funding of public works in the social sphere. }\end{array}$ \\
\hline $\begin{array}{l}\text { Kremenchuk - Effective } \\
\text { City Program }\end{array}$ & $\begin{array}{l}\text { Development and provision of information booklets, leaflets on topical } \\
\text { business issues. }\end{array}$ \\
\hline $\begin{array}{l}\text { Kremenchuk is a City } \\
\text { of Good People }\end{array}$ & $\begin{array}{l}\text { The submitted program will include several subprograms to support } \\
\text { non-protected sections of the population. }\end{array}$ \\
\hline $\begin{array}{l}\text { City Integrated Health } \\
\text { Programme }\end{array}$ & $\begin{array}{l}\text { The aim is to improve the demographic situation, preserve and promote } \\
\text { the health of citizens, improve the quality of health care. }\end{array}$ \\
\hline
\end{tabular}


Table 8, cont.

\begin{tabular}{|l|l|}
\hline \multicolumn{1}{|c|}{1} & \multicolumn{1}{|c|}{2} \\
\hline $\begin{array}{l}\text { Integrated Programme } \\
\text { Education of the City } \\
\text { of Kremenchuk }\end{array}$ & $\begin{array}{l}\text { The main task is to improve and develop the educational field of kremen- } \\
\text { chuk, to create favorable conditions for the development of a quality and } \\
\text { accessible education system. Creating conditions for students to partici- } \\
\text { pate in scholarships programs of international educational organizations. }\end{array}$ \\
\hline $\begin{array}{l}\text { Comprehensive } \\
\text { Programme } \\
\text { "Help" }\end{array}$ & $\begin{array}{l}\text { Collaboration with community organizations and charitable founda- } \\
\text { tions that help families with low income. Promoting the activities of } \\
\text { youth NGOs in organizing and conducting youth creative campaigns } \\
\text { and projects. }\end{array}$ \\
\hline $\begin{array}{l}\text { Comprehensive } \\
\text { Programme Environmental } \\
\text { Protection in Kremenchuk }\end{array}$ & $\begin{array}{l}\text { The purpose of the programme is to improve the existing state of Kre- } \\
\text { menchuk's natural environment. }\end{array}$ \\
\hline $\begin{array}{l}\text { Long-term Eco-city } \\
\text { Programme }\end{array}$ & $\begin{array}{l}\text { Identification of priority areas and implementation of a set of interrelat- } \\
\text { ed measures to minimize and prevent emissions and discharges of pol- } \\
\text { lutants into the environment, waste generation, proper containment } \\
\text { of green spaces. }\end{array}$ \\
\hline
\end{tabular}

Source: authors' elaboration

\section{Conclusion}

Hence, the essence of the concept of sustainable city development is based on three main components: economic, social, and environmental. The economic component is responsible for the effective development of small and medium-sized enterprises which provides the majority of jobs and provides to the saturation of the regional consumer goods market and directly influences the prospects of transition of economic complexes to the model of sustainable development. The social component is responsible for improving the well-being of city dwellers, improving living standards - internal and external, thus improving social conditions and standards. The environmental component is responsible for preserving and improving the natural environment.

\section{References}

Berdanova, O., Vakulenko, V., and Tertichka, V. (2008). Strategic planning, Lviv.

Characteristics of the Dnieper Basin during March 2019. (n.d.). Retrieved from http://www.mozmdv. gov.ua/wp-content/uploads/2019/06/YAkisnij-sajt-cherven.pdf

Kremenchuk City Development Strategy for the period to 2028. (n.d.). Retrieved from https://kremen. gov.ua/index.php/download/file/676496738766242656

Gerasymchuk, Z., and Vakhovich, I. (2002). Organizational and economic mechanism of formation and implementation of the strategy of regional development: Monograph. Lutsk: Publishing House LDTU. 
Katan, L.I. (2010). Napryami rozvitku upravlinnya agropromislovoyu sistemoyu Ukraini: Ekologo-ekonomichnij aspekt. Retrieved from http://library.kpi.kharkov.ua/Vestnik/2010_8/statiZKatan.pdf

Kratt, O., Pochtovyuk, A., Trunina, I., and Pryakhina, K. (2019). Marketing Positions of Kremenchuk Industrial Center in International Markets. (SHS Web of Conferences, 67, 01006).

Kvyatkovs'ka, L. A. (2013). Realizaciya principiv koncepciï stalogo rozvitkuv diyal'nosti. Visnik social'no-ekonomichnih doslidzhen', 85-89. Retrieved from http://nbuv.gov.ua/jpdf/Vsed_2013 1_14. pdf

Libanova, E., and Hvesyka, M. (Eds.). (2014). Socio-economic potential of sustainable development of Ukraine and its regions: A national report. Kyiv: Publishing House DU IEPCR NAN Ukraine.

Marchuk, L. P. (2014). Social'na vidpovidal'nist' yak viznachal'na strategiya rozvitku suchasnogo biznesu. Naukovij visnik Mikolä̈vs'kogo derzhavnogo universitetu imeni V.O. Suhomlins'kogo. Seriya: Ekonomichni nauki, 51-56.

Report on the Strategic Environmental Assessment of the Kremenchuk City Development Strategy for the period up to 2028. (n.d.). Retrieved from http://kremenchukinvest.com.ua

Shportko, A. M. (2018). Stanovlennya koncepciï stalogo rozvitku. Retrieved from http://www.ztu.edu. ua/ua/science/ conference/files/eco_es.../ShportkoAM.doc

Sushchenko, S., Trunina, I., and Khovrak, I. (2019). Big data in sustainable regional development: The digital future of smart regions. International Journal of 3D Printing Technologies and Digital Industry 3.2, 116-123.

The Program of Economic and Social Development of the Kremenchuk District for 2016-2018. (n.d.). Retrieved from http://kremenchuk.adm-pl.gov.ua/page/socialno-ekonomichniy-rozvitok

Vernihorova, N. V. (2019). Ecological urbanism as a factor of socio-economic and ecological development of modern cities and balanced use of nature. Economics and Law, 4(55), 108-115.

Vlasova, T.R. (2013). Social'na vidpovidal'nist' biznesu: Sutnist' ta tendenciï. Visnik Chernivec 'kogotorgovel'no-ekonomichnogo institutu ekonomichni nauki, 201(1), 52-57. 